\title{
STRATEGI KOMUNIKASI CORPORATE SOCIAL RESPONSIBILITY DI PT PERTAMINA (PERSERO) REGION IV WILAYAH JAWA TENGAH DAN DIY
}

\author{
Shoraya Lolyta Octaviana \\ (shorayalolytaoctaviana61@gmail.com) \\ Mahasiswa S1 Program Studi Ilmu Komunikasi Universitas Semarang
}

\begin{abstract}
Corporate social responsibility has become a global issue in the community and the company. CSR programs implemented by PT Pertamina (Persero) Region IV Regional Central Java and Yogyakarta in the areas of Education, Health, Environmental Conservation, Community Empowerment has been right on target. Corporate Social Responsibility program targeted, among others, so that more people know and use products - products Pertamina, as well as for good imaging Pertamina eyes of society. The communication strategy to the public (external strategies) used in the dissemination using print media such as newspapers and magazines nationally and locally. Electronic media using television and radio in Central Java and Yogyakarta as well as nationally. Communication strategies used in the dissemination to all employees of Pertamina, the media used in the form of intranet Pertamina, Energia magazine and TV Display. Theoretical basis used in this study is adopted from (Kottler, 2005) which states social initiatives of companies that can be taken for the implementation of CSR there are six forms of Cause Promotion, Cause Related Marketing, Corporate Social Marketing, Corporate Philanthropy, Community Volunteering and Socially Responsible Business Practices. The question in this research is how the Communication Strategy Corporate Social Responsibility (CSR) to PT Pertamina (Persero) Region IV Regional Central Java and Yogyakarta.
\end{abstract}

Kata Kunci : Komunikasi, Strategi, Sosial Responsibilitas

Latar Belakang Masalah

Akhir - akhir ini kerapkali terjadi kecelakaan dan musibah yang disebabkan oleh kalangan industri, sehingga menimbulkan persepsi buruk tentang industrial di kalangan masyarakat.Dengan era yang semakin maju dengan segala perkembangan di seluruh sektor kehidupan baik dalam sektor politik, ekonomi maupun sosial budaya membawa masyarakat untuk menghadapi persaingan ketat. Krisis moneter yang terjadi pada awal tahun
1998 mengakibatkan kondisi sosial ekonomi Indonesia mengalami gejolak sehingga tingkat kemiskinan semakin tinggi. Berdasarkan data yang terakhir dikeluarkan oleh Human Development Report tahun 2003 menunjukan bahwa Indonesia berada dalam index peringkat 112 dari 175 negara - negara miskin yang ada di dunia. (Buditama, Prasetijo dan Rudito, 2004)

Kondisi tersebut membawa kesadaran bahwa penanganan masalah nasional ini tidak cukup hanya 
diperhatikan pemerintah namun sebagian dari negara Indonesia maka seluruh komponen masyarakat perlu berpartisipasi dalam pembangunan. Corporate Sosial Responsibility (CSR) yang di artikan sebagai tanggungjawab sosial perusahaan merupakan paradigma baru yang memandang perusahaan sebagai bagian dalam masyarakat itu sendiri. Perusahaan dipandang sebagai suatu komunitas yang akan selalu mempunyai hubungan sosial dengan komunitas yang lainnya. Dalam paradigma ini kepedulian pihak perusahaan akan selalu dipertanyakan sebab telah menjadi bagian masyarakat yang lebih luas dimana apapun yang terjadi pada masyarakat, akan mempengaruhi perusahaan dan sebaliknya.

PT Pertamina (Persero) merupakan salah satu perusahaan BUMN besar di Indonesia yang menerapkan Corporate Social Responsibility (CSR) sejak tahun 1993, program tersebut sebagai wujud kepedulian perusahaan terhadap perkembangan masyarakat Indonesia ke arah yang lebih baik. Dibentuknya seksi CSR pada bagian Hubungan Masyarakat (Humas) secara terstruktur menunjukkan keseriusan PT Pertamina dalam menjalankan program Corperate Social Responsibility.

\section{Perumusan Masalah :}

Bagaimana Strategi Komunikasi Corporate Social Responsibility (CSR) di PT Pertamina (Persero) Region IV Wilayah Jawa Tengah dan DIY ?

\section{Tujuan Penelitian :}

Untuk mengetahui Strategi Komunikasi Corporate Social Responsibility (CSR) di PT Pertamina (Persero) Region IV Wilayah Jawa Tengah dan DIY

\section{KAJIAN TEORI}

Menurut (Kotler, 2005) menyebutkan disini terdapat enam opsi dalam six options for doing goods sebagai inisiatif sosial perusahaan yang dapat ditempuh dalam rangka implementasi CSR.

\section{Cause Promotion}

Dimana suatu perusahaan dapat memberikan dana atau berbagai macam kontribusi lainnya ataupun sumberdaya perusahaan lainnya untuk meningkatkan kesadaran masyarakat atas isu sosial tertentu, ataupun dengan cara mendukung pengumpulan dana, partisipasi dan rekruitmen sukarelawan untuk aksi sosial tertentu.

2. Cause-Related Marketing

Yang dalam hal ini suatu perusahaan berkomitmen untuk berkonstribusi atau menyumbang sekian persen dari pendapatannya, dari penjualan suatu produk tertentu miliknya untuk isu sosial tertentu.

3. Corporate Social Marketing

Dimana suatu perusahaan dapat mendukung perkembangan atau pengimplementasian kampanye untuk merubah cara pandang maupun tindakan guna meningkatkan kesehatan publik, keamanan, lingkungan dan kesejahteraan masyarakat.

\section{Corporate Philanthropy}

Dalam hal ini, suatu perusahaan secara langsung dapat memberikan 
sumbangan, biasanya dalam bentuk uang tunai. Pendekatan ini merupakan bentuk implementasi sosial yang paling tradisional.

5. Community Volunteering

Perusahaan dalam hal ini dapat mendukung dan mendorong pegawainya, mitra bisnis maupun para mitra waralabanya untuk menjadi sukarelawan di organisasi organisasi kemasyarakatan lokal.

6. Socially Responsible Business Practices

Perusahaan dapat mengadopsi dan melakukan praktek - praktek bisnis dan investasi yang dapat mendukung isu - isu sosial guna meningkatkan kelayakan masyarakat dan juga melindungi lingkungan.

\section{METODOLOGI PENELITIAN}

\section{Jenis Penelitian}

Jenis penelitian yang digunakan dalam penelitian ini adalah penelitian deskriptif kualitatif (Moleong, 2005) yaitu peneliti harus dapat mengetahui kedudukannya pada saat pengumpulan data dilapangan. Peneliti dalam penelitian deskriptif kualitatif bertindak sebagai alat pengumpul dan penafsir data. Hal tersebut dilakukan karena jika memanfaatkan alat yang bukan manusia dan mempersiapkan dirinya terlebih dahulu sebagai yang lazim digunakan dalam penelitian klasik, maka sangat tidak mungkin untuk mengadakan penyesuaian terhadap kenyataan dilapangan.

\section{Teknik Sampling}

Teknik sampling yang digunakan dalam penelitian ini adalah purposive sampling. Menurut (Sugiyono, 2009) teknik purposive sampling adalah teknik pengambilan sampel dari sumber data dengan pertimbangan tertentu.

\section{Teknik Pengumpulan Data}

a. Penelitian Lapangan

Wawancara mendalam maksudnya adalah peneliti mencari data dengan mewawancarai secara mendalam keseluruhan sumber yang berkaitan dengan Strategi Komunikasi CSR pada PT Pertamina (Persero) Region IV Wilayah Jawa Tengah dan DIY, yaitu dengan pimpinan, staff dan karyawan dengan departemen yang berkaitan yaitu bagian Humasnya.Observasi Langsung / Pengamatan

b. Observasi Langsung / Pengamatan

Teknik pengumpulan data dengan mengadakan pengamatan terhadap obyek yang di teliti, dimana dengan teknik observasi ini, peneliti mengamati bagaimana strategi komunikasi yang digunakan dalam program CSR di PT Pertamina (Persero) wilayah Jawa Tengah dan DIY.

\section{Teknik Analisis Data}

a. Data Reductionyaitudata yang diperoleh dari lapangan jumlahnya cukup banyak, untuk itu maka dicatat secara rinci dan 
teliti. Mereduksi data berarti merangkum, memilih hal - hal yang pokok, memfokuskan pada hal - hal yang penting, dicari tema dan polanya.

b. Data Display yaitu setelah data di reduksi, maka langkah selanjutnya adalah penyajian data. Dalam penyajian data bisa dilakukan dalam bentuk uraian singkat, bagan, hubungan antar kategori, flowchart dan sejenisnya. Yang paling sering digunaka untuk penyajian data dalam penelitian kualitatif adalah dengan teks yang bersifat naratif.

c. Conclusion Drawing Verification yaitu langkah ketiga dalam analisis data kualitatif menurut Miles dan Huberman dalam (Soegiyono 2005) adalah penarikan kesimpulan dan verivikasi.

\section{Corporate Social Responsibility (CSR)} PT Pertamina (Persero) Region IV Wilayah Jawa Tengah dan DIY

CSR meliputi dua program utama yaitu Community Relations (Comrel) dan Community Development (Comdev). Comrel diwujudkan dengan pemberian bantuan sosial yang sifatnya tidak berkelanjutan. Comdev merupakan kegiatan pengembangan masyarakat yang dilakukan secara sistematis, terencana dan di arahkan untuk memperbesar akses masyarakat guna mencapai kondisi sosial, ekonomi dan kualitas kehidupan yang lebih baik secara mandiri.

Wilayah dan sasaran program CSR yaitu Ring I (stakeholder yang terkena dampak langsung kegiatan operasi perusahaan berada disekitar Kantor Unit / lokasi), Ring II (stakeholder yang terkena dampak tidak langsung kegiatan operasi perusahaan berada di Kota / Kabupaten yang sama dengan Kantor Unit / Lokasi), Ring III (stakeholder yang berada diwilayah kerja operasi perusahaan diluar ring I dan ring II berada di provinsi yang sama dengan Kantor Unit / Lokasi).

\section{Strategi Komunikasi Corporate} Social Responsibility (CSR) di PT Pertamina (Persero) Region IV Wilayah Jawa Tengah dan DIY

Strategi yang digunakan oleh Pertamina menggunakan teori inisiatif perusahaan Cause Promotion, Corporate Social Marketing, Corporate Philanthropy dan Community Volunteering. Pertamina dalam mempublikasi program - program CSR kepada masyarakat menggunakan media cetak dan media elektronik. Contohnya pada program pelatihan untuk guru guru Pertamina bekerja sama dengan Harian Suara Merdeka, untuk program Kanker Serviks media yang digunakan Jawa Pos. Pertamina memilih media yang berpengaruh di Jawa Tengah dan DIY untuk bekerjasama dikarenakan target pemberitaannya sampai ke khalayak umum.

Strategi komunikasi yang dilakukan masing - masing program berbeda karena tergantung dengan sasaran program, divisi External Relations melakukan komunikasi dengan pihak eksternal dengan melalui press conference dan memberikan press release kepada semua media cetak yang dianggap berpengaruh di wilayahnya.

Berikut adalah media - media yang bekerjasama dengan Pertamina 
dalam sosialisasi program CSR ke masyarakat dan stakeholdernya. Media cetak nasional yang digunakan yaitu Kompas, Media Indonesia, Bisnis Indonesia, Jawa Pos, Koran tempo dan Majalah Tempo. Media cetak lokal yang digunakan meliputi Kedaulatan Rakyat, Suara Merdeka, Radar Semarang, Radar Tegal, Radar Purwokerto, Wawasan, Harian Semarang, Jateng Pos, Yogyakarta Pos, Solo Pos dan Warta Jateng. Pertamina bekerjasama dengan TV lokal maupun nasional seperti Metro TV, Trans TV, SCTV, TV one, Cakra TV, TVRI Jateng, TVRI Jogja, Pro TV, TA TV Solo, Borobudur TV dan TV KU. Untuk Radionya Pertamina bekerjasama dengan hampir seluruh radio di Jawa Tengah dan DIY untuk sosialisasi CSR seperti radio RRI pusat, RRI Jawa Tengah, Gajahmada Fm, Damashinta Pekalongan, Radio Idola, Trax Fm, Sonora Semarang, Solo Fm, Sonora Yogyakarta dan lain sebagainya. Menurut teori (Jefkins, 1992) mengenai media PR hal ini sesuai dengan pilihan media yang digunakan External Relation (Humas) yang berlandaskan berbagai tujuan dan jenis sasaran khalayak.

Selain itu Pertamina mengadakan program press tour yaitu mengajak beberapa media ketempat - tempat dari usaha hilir sampai usaha hulu, mulai dari tempat pengilangan minyak sampai ke pendistribusiannya, kegiatan press tour ini bertujuan untuk menginformasikan bahwa untuk menjadi produk siap konsumsi seperti bensin, solar, pertamax, gas LPG, oli, avtur dan produk lainnya itu tidak mudah dan diharapkan masyarakat bisa berhemat dengan produk Pertamina tersebut. Press tour yang sudah pernah dilaksanakan berupa kunjungan ke blok Cepu. Tujuan CSR dalam kegiatan ini berupa pencitraan atau membangun brand image perusahaan di mata stakeholder.

Pertamina menggunakan intern media untuk sosialisasi program CSR diantaranya intranet yaitu media publikasi berita atau artikel yang disampaikan melalui http://intranet.pertamina untuk mengkomunikasikan program - program CSR dengan karyawannya karena ini merupakan media internal yang bisa di akses seluruh karyawan. Media cetak Energia yang terbit mingguan di majalah tersebut terdapat dua halaman khusus meliput kegiatan CSR Pertamina Jateng dan DIY. Ada juga Pertamina TV tetapi untuk publikasi kegiatan CSR secara nasional. Seperti yang di utarakan (Effendy, 2004) strategi komunikasi yang mempertimbangkan komunikator dan pemilihan media yang disesuaikan dengan tujuan pesan komunikasi serta sasaran komunikasi sesuai dengan teori korelasi antar komponen dalam strategi komunikasi.

Setiap karyawan Pertamina seharusnya mengetahui program CSR karena informasi dari TV Display yang berada di lobby Kantor Pertamina, di jalan kantor yang strategis dengan menyajikan program - program Pertamina termasuk CSR didalamnya. Hampir semua program CSR dikomunikasikan ke publik melalui press release dan pada saat melakukan komunikasi perlu memperhatikan sasaran komunikasinya. Setelah itu memilih media yang sesuai dengan sasaran komunikasi tersebut. 
Pertamina memiliki kepentingan untuk membina hubungan baik, saling pengertian, dan semangat kerjasama sehingga nama baik dan legimitasi perusahaan tetap terjaga. PT Pertamina juga memiliki strategi yang bagus dan tepat dengan melakukan berbagai upaya untuk pemberdayaan potensi masyarakat di lingkungankegiatan usaha Pertamina dan Pertamina berkomitmen untuk mendukung perkembangan masyarakat Jawa Tengah dan DIY khususnya lewat program - program CSR nya.

Melalui program CSR nya Pertamina ingin melakukan perubahan untuk semakin dipercaya masyarakat melalui dedikasi yang tinggi serta memegang teguh komitmen untuk melakukan pemberdayaan potensi masyarakat yang berada di lingkungan kegiatan perusahaan. Untuk PT Pertamina (Persero) Region IV wilayah Jawa Tengah dan DIY, hasil perubahan ini mulai tampak, dapat kita lihat dari respon masyarakat yang antusian untuk mengikuti seluruh program CSR yang ada di Pertamina dan hubungan harmonis yang terjalin antara masyarakat dan seluruh staff dan karyawan PT Pertamina tentunya melalui strategi strategi komunikasi yang sudah dijalankan.

CSR sebagai program Pertamina, sudah dijalankan sejak tahun 1993. Corporate Social Responsibility merupakan suatu bentuk tanggungjawab sosial perusahaan serta komitmen perusahaan untuk memberi kontribusi nyata pada peningkatan ekonomi dan kualitas hidup pekerja dan keluarganya, di samping komunitas lokal dan serta masyarakat keseluruhan. CSR dilakukan perusahaan untuk mempertahankan image positif di mata stakeholdernya. Dibagian External Relation, terdapat satu divisi yang menjalankan dan bertanggungjawab dengan program CSR yaitu divisi Community Development yang di bawahi oleh Reno F. Daryanto. Di Pertamina terdapat empat program yang menjadi fokus CSR antara lain bidang kesehatan, lingkungan, pemberdayaan masyarakat dan konservasi lingkungan.

CSR bisa dijalankan melalui prosedur - prosedur yang harus dilewati, antara lain pihak ke-III mengajukan surat permohonan kepada perusahaan melalui GM atau melalui Kepala Depot / DPPU / Instalasi / Cabang. Kebutuhan CSR (Comdev / Comrel) bisa juga datang dari internal perusahaan berupa proposal hasil penelitian strategis berdasarkan sosial mapping. Surat atau hasil penelitian strategis diterima GM, selanjutnya GM memberikan disposisi kepada Humas. Surat yang diterima melalui Kepala Depot diteruskan ke Humas. Humas membuat kajian kelayakan dan pembebanan anggaran. Terhadap permohonan yang diputuskan tidak layak dipenuhi, disampaikan surat balasan yang ditandatangani oleh Humas. Apabila layak, Humas membuat kajian pembebanan anggaran apakah menggunakan anggaran Comdev atau PKBL. Apabila masuk dalam program Comdev maka menggunakan anggaran Comdev dengan nota permohonan persetujuan langsung diajukan ke GM. GM memberikan persetujuan dan meneruskan kepada Humas. Humas memproses keuangannya melalui Fungsi Keuangan berdasarkan persetujuan GM. 
Program-program CSR ini antara lain:

\section{Kesehatan}

Dibidang kesehatan dalam rangka ulang tahun ke-55 Pertamina mengadakan kegiatan "Bhakti Sosial Pengobatan Gratis Kanker Serviks" pada tanggal 7 Desember 2012 yang bertempat di Poliklinik Pertamina Semarang dan Poliklinik Pertamina Yogyakarta. Program sehat bersama Pertamina sebagai salah satu program CSR Pertamina dalam bidang kesehatan yang merupakan bentuk kepedulian Pertamina terhadap kesehatan masyarakat.

\section{Pendidikan}

Pertamina memiliki kegiatan CSR dibidang pendidikan dalam rangka memperingati hari anak nasional, Pertamina Pemasaran Jateng \& DIY menyalurkan 1500 Beasiswa senilai Rp 730 juta kepada siswa-siswi SD-SMA di wilayah Jawa Tengah \& DIY pada tanggal 27 Juli 2012. Penyaluran beasiswa ini merupakan salah satu CSR Pertamina di bidang pendidikan dengan Tema Cerdas Bersama Pertamina. Selain beasiswa, kepada murid-murid juga diberikan tas sekolah berikut perlengkapan sekolah berupa alat tulis dan buku tulis 'Satu Buku Sejuta Ilmu' sebanyak total 16.500 buku. Selain beasiswa, beberapa program CSR Pertamina yang akan dilakukan dalam rangka memperingati Hari Anak Nasional antara lain Operasi Bibir Sumbing bagi penderita cacat bawaan bibir sumbing dari keluarga yang tidak mampu dan Program Rumah Pintar di area pasar Johar sebagai wadah tempat anak-anak jalanan dan komunitas di sekitarnya mendapatkan pendidikan, pelatihan dan keterampilan.

\section{Konservasi Lingkungan}

Untuk program konservasi lingkungannya, Pertamina terus melakukan upaya untuk meningkatkan pelestarian lingkungan, hal ini diwujudkan melalui aksi Penanaman 55.000 pohon di berbagai wilayah di Jateng dan DIY dalam rangka HUT ke-55. Penanaman diawali di kawasan Pantai Desa Tanggultlare, Kecamatan Kedung, Kabupaten Jepara, Jawa Tengah pada tanggal 1 Desember 2012.

\section{Pemberdayaan Masyarakat}

Pertamina memiliki program desa binaan di desa Tambakrejo, Semarang. PT Pertamina bekerja sama dengan Universitas Negeri Semarang (Unnes) meresmikan rumah pintar "Patra Sutera" yang berlokasi di Tambakrejo RW XI Kelurahan Tanjungmas Kecamatan Semarang Utara. Keberadaan rumah pintar tersebut untuk memfasilitasi warga dalam mendapatkan pendidikan yang layak. Adapun pemberdayaan masyarakat yang dikembangkan di wilayah Tambakrejo RW XI binaan Unnes dan PT Pertamina di antaranya, peternakan bebek, pengolahan limbah plastik, pembuatan telur asin dan terasi, serta lain sebagainya.Selain meresmikan rumah pintar, dengan dibantu koordinator desa binaan dari Unnes Nana Kariada, mereka meninjau lokasi penanaman mangrove. 


\section{Program Cause Related Marketing}

Biasanya dilakukan melalui program promosi seperti pada event Pertamina Pelumas Fastron bersama Community Yamaha di Javamall Semarang pada tanggal 8 Februari 2012, CSR ikut serta andil dengan mensponsori berupa pemberian voucher Pertamax senilai $\mathrm{Rp}$ 10.000 berjumlah 500 lembar. Tujuannya event ini adalah untuk brand image perusahaan serta agar masyarakat mengetahui produk Pertamina dan menggunakan produk Pertamina.

\section{Kesimpulan}

Corporate Social Responsibility adalah komitmen perusahaan untuk memberi kontribusi nyata pada peningkatan ekonomi dan kualitas hidup pekerja dan keluarganya, di samping komunitas lokal dan serta masyarakat keseluruan.CSR dilakukan perusahaan untuk mempertahankan image positif di mata stakeholdernya.

Sasaran program Corporate Social Responsibilityantara lain agar masyarakat lebih mengetahui da menggunakan produk - produk Pertamina, serta untuk pencitraan yang baik Pertamina dimata masyarakat.

Dalam mengkomunikasikan program Corporate Social Responsibility PT Pertamina Region IV menggunakan strategi Cause Promotion, Corporate Social Marketing, Corporate Philanthropy dan Community Volunteering sesuai dengan teori (Kotler, 2005). Strategi media yang digunakan untuk sosialisasi program Corporate Social Responsibilitykepada masyarakat terbagi menjadi dua macam yaitu ekstern media dan intern media.

\section{Saran}

Dari setiap program Corporate Social Responsibility di lapangan dan pada praktiknya tentu saja akan mengalami kendala dalam sosialisasi kepada masyarakat. Untuk itu Penulis menyarankan diperlukan laporan strategi CSR yang digunakan oleh Pertamina di masing - masing program dan evaluasi setelah dilaksanakan programnya tersebut apakah sudah tepat sasaran atau belum dalam penyampaian pesan komunikasinya.

\section{Daftar Pustaka}

Effendy Onong Uchjana. 2004. Ilmu komunikasi dan praktek. Bandung: PT Remaja Rosdakarya

Kotler, Philip., \& Nancy Lee. 2005. Corporate Social Responsibility. New Jersey : John Willey \& Sons

Sugiyono. 2005. Memahami Penelitian Kualitatif. Bandung : CV Alfabet 
